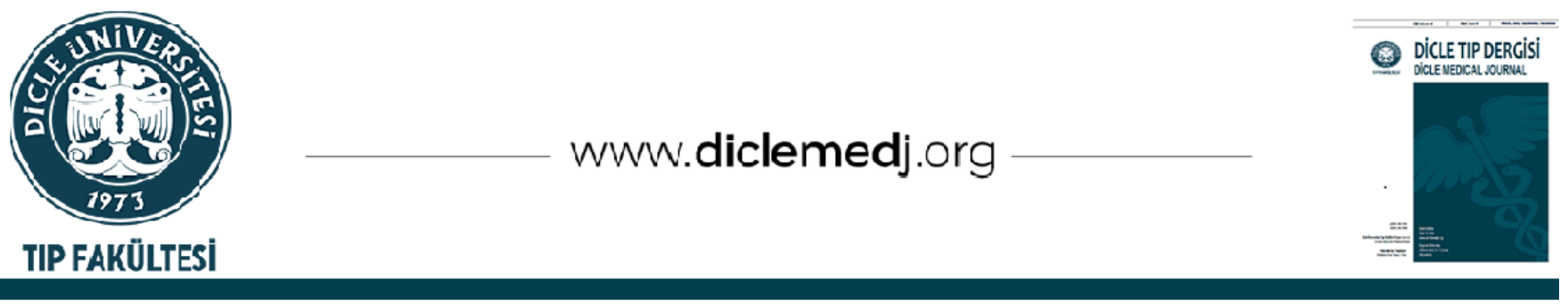

Original Article / Özgün Araştırma

\title{
The Relationship Between Transthoracic Echocardiography Findings, Localization of Stroke, and Risk Factors in Patients With Ischemic Stroke
}

\author{
Cihat Uzunköprü ${ }^{\text {D }}$, Enise Nur Özlem Tiryaki ${ }^{\text {D }}$ 1, Mücahit Tiryaki ${ }^{\text {D }} 2$ \\ 1. Izmir Katip Celebi University, Faculty of Medicine, Department of Neurology Izmir, Turkey \\ 2. İmir Katip Çelebi University, Faculty of Medicine, Department of Cardiology Izmir, Turkey
}

Received: 10.02.2021; Revised: 08.04.2021; Accepted: 14.04.2021

\begin{abstract}
Objective: Ischemic stroke is one of the common neurological pathology. Identifying the risk factors and treating cardiac pathologies play an important role in preventing ischemic stroke stroke. In this study, we aimed to examine the relationship between transthoracic echocardiography findings, localization of ischemia and the etiology of stroke.

Methods: We included 149 patients with ischemic stroke who were followed up at Neurology Department of İzmir Katip Çelebi University Atatürk Training and Research Hospital between January 2018-January 2019. Demographic characteristics of the patients, etiology and localization of stroke, presence of cardiac arrhythmias, and transthoracic electrocardiography findings were recorded and the relationship between these parameters were examined.

Results: We enrolled 81 female (54.4\%) and 68 male (45.6\%) patients in this study. The mean age was 68.03 12.35 . $84.6 \%$ of the patients have atherosclerotic and $15.4 \%$ have cardioembolic stroke. The most common risk factor was hyperlipidemia. Atrial fibrillation was detected in $21.1 \%$ of the patients. While atrial fibrillation was more common in patients with cardioembolic stroke, smoking was more common in patients with atherosclerotic stroke. Although most patients had multiple risk factors prior to stroke, almost half of the patients did not use any antiaggregant or anticoagulant therapy. Cardioembolic strokes were positively correlated with greater left atrium width. There was no correlation between transthoracic electrocardiography findings and stroke location.
\end{abstract}

Conclusion: Determination of risk factors in patients with ischemic stroke, investigation of cardiac pathologies, and applying appropriate treatments are important in terms of preventing both new and recurrent stroke development.

Key words: Stroke, transthoracic echocardiography, atrial fibrillation, localization of stroke

DOI: $10.5798 /$ dicletip.944317

Correspondence / Yazışma Adresi: Cihat Uzunköprü, IIZzmir Katip Çelebi University, Faculty of Medicine, Department of Neurology Izmir, Turkey Post Code: 35360 e-mail: cihat.uzunkopru@ikc.edu.tr 


\section{İskemik İnmeli Hastalarda Transtorasik Ekokardiografi Bulguları ile İnme Lokalizasyonu ve Risk Faktörleri Arasındaki İlişki}

Öz

Giriş: İskemik inme sık görülen nörolojik patolojilerden birisidir. Eşlik eden risk faktörlerinin ve kardiyak patolojilerin saptanması ve tedavi edilmesi hem yeni gelişimli hem de tekrarlayıcı bir inmenin engellenmesi açısından önemli yer tutar. Bu amaçla çalışmamızda inme geçiren hastaların Elektrokardiyografi bulguları ile inme özellikleri ve risk faktörleri arasındaki iliş̧inin incelenmesi amaçlanmıştır.

Yöntemler: Bu çalışmaya 2018-2019 yılları arasında İzmir Katip Çelebi Üniversitesi Atatürk Eğitim ve Araştırma Hastanesi Nöroloji Kliniğinde 'İskemik İnme’ tanısı alan 149 hasta dahil edildi. Hastaların demografik özellikleri, inmenin etyolojisi, lokalizasyonu, kardiyak aritmi varlığı ve Elektrokardiyografi bulguları kayıt altına alındı ve bu parametrelerin birbirleri ile olan ilişkileri incelendi.

Bulgular: Çalışmaya alınan 81'i kadın (\%54.4) ve 68'i erkek (\%45.6) olmak üzere toplam 149 hastanın yaş ortalamaları 68.03 12.35'ti. Hastaların \%84.6'sı aterosklerotik doğada inme geçirirken \%15.4 hastada kardiyoembolik inme saptandı. En sık görülen risk faktörü \%89.9 hastada görülen hiperlipidemi idi. Hastaların \%21.1'inde atriyal fibrilasyon saptandı. Kardiyoembolik inme geçiren hastalarda atriyal fibrilasyon daha sık izlenirken aterosklerotik inmeli hastalarda sigara kullanımı daha sık izlendi. Hastaların yaklaşık yarısının inme geçirmeden önce çoklu risk faktörü içermesine karşın herhangi bir antiagregan ya da antikoagülan tedavi kullanmadığı görüldü. Sol atriyum genişliği fazla olan hastalarda kardiyoembolik inmelerin daha sık olduğu gözlendi. Elektrokardiyografi bulguları ile inme lokalizasyonu açısından herhangi bir ilişki ise saptanmadl.

Sonuç: İskemik inmeli hastalarda risk faktörlerinin tayini, kardiyak patolojilerin derinlemesine araştırılması ve gerekli tedavilerin uygulanması hem yeni inme hem de tekrarlayıcı inme gelişiminin önüne geçmek açısından önemli yer tutmaktadır.

Anahtar kelimeler: İnme, Ekokardiografi, Atriyal fibrilasyon, inme lokalizasyonu.

\section{INTRODUCTION}

Ischemic stroke is a syndrome that occurs due to cerebral, spinal, or retinal infarction and has symptoms related to focal neurological dysfunction. Symptoms last longer than 24 hours or result in death. Besides, the distribution of stroke types are $80 \%$ ischemic and $20 \%$ hemorrhagic ${ }^{1}$, and the distribution of ischemia should conform to a specific vascular location ${ }^{2}$. Ischemic stroke may develop due to the atherosclerosis of cerebral arteries, small vessel disease, systemic hypoperfusion, or cardioembolic etiology. Although atherosclerosis is the most common reason of ischemic stroke, cardioembolic stroke incidence is gradually increasing ${ }^{3}$. $15-20 \%$ of ischemic strokes are related to cardioembolic etiology in elderly patients, but this rate increases to $35 \%$ in patients with younger age ${ }^{4}$. The most common localization of ischemic stroke is middle cerebral artery (MCA) territory. The anterior cerebral artery (ACA), vertebrobasilar artery (VBA), and the posterior cerebral artery (PCA), less frequently, maybe the reason for ischemic stroke ${ }^{5}$. There are many risk factors for ischemic stroke, including hypertension (HT), diabetes mellitus (DM), coronary heart diseases (CAD), congestive heart failure (CHF), smoking and alcohol consumption, hyperlipidemia (HPL), inappropriate diet, physical inactivity, abdominal obesity, and prosthetic heart valves. It is essential to control these risk factors in primary and secondary prophylaxis ${ }^{6,7}$.

The most common reason for death is the circulatory system diseases in our country as well as in the whole world ${ }^{8,9}$; therefore, detection and treatment of cardiac risk factors is mandatory to prevent both the first ischemic stroke and recurrences ${ }^{10}$. It is observed that 
patients with ischemic stroke have different cardiac pathologies such as atrial fibrillation $(\mathrm{AF}), \mathrm{CAD}$, pulmonary hypertension, prosthetic heart valves, patent foramen ovale (PFO), and previous myocardial infarction. Therefore, to evaluate cardiac structure and arrhythmias, Transthoracic Echocardiography (ECHO) and Holter Electrocardiography (H-ECG) should be performed in all patients with ischemic stroke ${ }^{11}$. The H-ECG alone is not enough to evaluate cardiac rhythm disorders in patients with younger age. If stroke location or distribution is suggestive of cardioembolic stroke, H-ECG should be performed for at least 24 hours, and if necessary, this period should be extended ${ }^{12}$. The treatment response of ischemic stroke is getting much better, but the social and economic costs of stroke are still increasing due to the aging of the general population. Therefore, the idea of treating classical risk factors of ischemic stroke and defining new risk factors has gained importance. In this study, we aimed to evaluate the relationship between stroke localizations, risk factors, and transthoracic ECHO findings in patients with ischemic stroke.

\section{METHODS}

This study was approved by the İzmir Katip Çelebi University Faculty of Medicine Ethics Committee (Decision Date: 22.10.2020, 1005 Approval Number). It was conducted in accordance with the Helsinki Declaration, and informed consent was provided by all the participants.

Clinical and demographic data, previous stroke localizations, co-morbid diseases, H-ECG findings, current treatments, and transthoracic ECHO findings of patients were retrospectively evaluated. We classified types of ischemic stroke as cardioembolic and atherosclerotic stroke according to magnetic resonance imaging (MRI). In addition, infarction areas in MRI were classified as ASA, MCA, and VBS territories. We classified cardiac rhythms as sinus rhythm (SR), AF, and paroxysmal $\mathrm{AF}$ (PAF) in H-ECG examination. HR, HT, DM, HPL, chronic renal failure (CRF) were questioned as risk factors in the medical history of the patients. Antiaggregant and anticoagulant drugs were classified as acetylsalicylic acid, clopidogrel, warfarin sodium, and other oral anticoagulants. Ejection fraction (EF), left atrium (LA) width, aortic root diameter, left ventricular wall motion abnormalities (LVWMA) were evaluated in patients who underwent transthoracic ECHO examination.

\section{Statistics}

Statistical analysis of the data was performed using SPSS 22.0 (IBM Corporation, Armonk, NY, USA) package program. In data analysis, the distribution of continuous variables was determined with the Shapiro-Wilk normality test. Descriptive statistics were shown as mean and standard deviation or minimum-maximum for continuous variables, and as the case number and (\%) for categorical variables. The relationship between qualitative variables was examined using the Pearson Chi-square test. Values of $p<0.05$ for all tests were considered statistically significant.

\section{RESULTS}

We included 149 patients (54.4\% females) with ischemic stroke in this study. The mean age was $68.03 \pm 12.35$. According to the distribution of stroke territory on MRI, $84.6 \%$ of the patients had atherosclerotic stroke, while $15.4 \%$ had cardioembolic stroke. We observed that 83 patients $(55.7 \%)$ had MCA infarction, 57 patients (38.3\%) had VBS infarction, and 9 patients (6\%) had ACA infarction. $76.5 \%$ of the patients had their first stroke; however, $23.5 \%$ of the patients had a history of $\geq 2$ recurrences. We detected SR in 119 (79.9\%) patients; in addition, 30 patients $(21.1 \%)$ had $\mathrm{AF}$ and PAF (Table 1). The risk factors were the following: 39 patients $(26.2 \%)$ had CAD, 111 patients (74.5\%) had HT, 75 patients (50.3\%) had DM, 
134 patients (89.9\%) had HPL, 35 patients (23.5\%) had CRF, and 64 patients (42.9\%) had a smoking history. The distribution of the previous treatments showed that $39.5 \%$ of patients were receiving ASA, 2\% clopidogrel, $5.4 \%$ warfarin sodium, $2 \%$ rivaroxaban, $1.3 \%$ dabigatran, and $0.7 \%$ apixaban. $49 \%$ of the patients did not receive any antiaggregant or anticoagulant treatment. In the analysis of transthoracic ECHO findings, we observed that EF was under $50 \%$ in 14 patients (9.3\%), left atrium was wide in 42 patients (28.1\%), and pulmonary artery pressure was high in 24 patients (16.1). In addition, 39 patients (26.1\%) had left ventricle wall motion abnormalities (Table 2). Transesophageal ECHO was applied to 10 patients for further investigation, however, we did not detect any additional pathology. We examined the association between stroke etiology, stroke localizations, and ECHO findings. We observed that cardioembolic strokes were higher in patients with greater left atrium width than atherosclerotic strokes $(p=0.03)$, while other ECHO parameters did not have any effect on the etiology of ischemic stroke (Table III). Additionally, cardiac abnormalities detected on ECHO have no effect on the stroke localization and the involvement of specific vascular territory $(p>0.05)$. The evaluation of risk factors and stroke etiology showed that nearly all patients with AF have cardioembolic stroke $(\mathrm{p}<0.01)$, and atherosclerotic strokes were significantly more common than cardioembolic strokes in smokers ( $p=0.03)$. Receiving any antiaggregant or anticoagulant treatment prior to stroke has no effect on the development of cardioembolic or atherosclerotic stroke $(p=0.166)$.
Table I: Demographic and clinical data oh of the patients

\begin{tabular}{|c|c|}
\hline Demographics & $(n=149)$ \\
\hline Age, mean $\pm S D$ (range) & $68.03 \pm 12.35(27-94)$ \\
\hline Female/Male n (\%) & 81 (54.4\%) / 68 (45.6\%) \\
\hline \multicolumn{2}{|l|}{ Stroke Type } \\
\hline Atherosclerotic & $126(84.6 \%)$ \\
\hline Cardioembolic & $23(15.4 \%)$ \\
\hline \multicolumn{2}{|c|}{ Involvement of Artery Territory } \\
\hline MCA & 83 (55.7.\%) \\
\hline VBS & 57 (38.3\%) \\
\hline ASA & $9(6.0 \%)$ \\
\hline \multicolumn{2}{|l|}{ Cardiac Rhythm } \\
\hline Sinus rhythm & 119 (79.9\%) \\
\hline $\mathrm{AF}$ & $25(16.8 \%)$ \\
\hline PAF & $5(3.4 \%)$ \\
\hline \multicolumn{2}{|l|}{ Number of stroke } \\
\hline First stroke & 114 (76.5\%) \\
\hline 2. stroke & $31(20.8 \%)$ \\
\hline$\geq 3$ stroke & $4(2.7 \%)$ \\
\hline
\end{tabular}

MCA: Middle cerebral artery, VBS: Vertebrobasilar system, ASA: Anterior cerebral artery AF: Atrial fibrillation, PAF: Paroxysmal atrial fibrillation 
Table II: Risk factors, ECHO findings, and treatments prior to stroke

\begin{tabular}{|c|c|}
\hline Risk Factors & $n=149$ \\
\hline Coronary Artery Disease & $39(26.2 \%)$ \\
\hline Hypertension & $111(74.5 \%)$ \\
\hline Diabetes Mellitus & $75(50.3 \%)$ \\
\hline Smoking & $64(42.9 \%)$ \\
\hline Hyperlipidemia (LDL>100 mg/dl) & $134(89.9 \%)$ \\
\hline Chronic Kidney Failure & $35(23.5 \%)$ \\
\hline ECHO Findings & $n=149$ \\
\hline Ejection Fraction $<\% 50$ & $14(9.3 \%)$ \\
\hline Left Atrium Width & $42(28.1 \%)$ \\
\hline $\begin{array}{lll}\text { Elevated } & \text { Pulmonary } & \text { Artery } \\
\text { Pressure } & & \end{array}$ & $24(16.1 \%)$ \\
\hline $\begin{array}{l}\text { Left Ventricle Wall Motion } \\
\text { Abnormality }\end{array}$ & $39(26.1 \%)$ \\
\hline Aortic Root Width (>40 mm) & $0(0 \%)$ \\
\hline Treatments Prior to Stroke & $n=149$ \\
\hline Acetylsalicylic acid & $59(39.6 \%)$ \\
\hline Clopidogrel & $3(2 \%)$ \\
\hline Warfarin sodium & $8(5.4 \%)$ \\
\hline Rivaroxaban & $3(2 \%)$ \\
\hline Dabigatran & $2(1.3 \%)$ \\
\hline Apixaban & $1(0.7 \%)$ \\
\hline No treatment & $73(49 \%)$ \\
\hline
\end{tabular}

Table III: The Relationship Between Localization, ECHO Findings and Risk Factors

Etiology,

\begin{tabular}{|c|c|c|}
\hline & & $\mathbf{p}$ \\
\hline \multicolumn{3}{|l|}{ Stroke Etiology } \\
\hline \multirow{6}{*}{$\begin{array}{l}\text { (Atherosclerotic- } \\
\text { Cardioembolic) }\end{array}$} & Ejection Fraction & 0.375 \\
\hline & LVWMA & 0.363 \\
\hline & Left Atrium Width & 0.03 \\
\hline & Aortic Root Width & 0.603 \\
\hline & Elevated Pulmonary & \\
\hline & Artery Pressure & 0.724 \\
\hline \multirow[t]{6}{*}{ Stroke Localization } & Ejection Fraction & 0.681 \\
\hline & LVWMA & 0.487 \\
\hline & Left Atrium Width & 0.984 \\
\hline & Aortic Root Width & 0.170 \\
\hline & Elevated Pulmonary & \\
\hline & Artery Pressure & ST. \\
\hline \multicolumn{3}{|l|}{ Stroke Etiology } \\
\hline \multirow[t]{9}{*}{$\begin{array}{l}\text { (Atherosclerotic- } \\
\text { Cardioembolic) }\end{array}$} & $\begin{array}{l}\text { Coronary } \\
\text { Disease }\end{array}$ & 0.119 \\
\hline & Hypertension & 0.944 \\
\hline & Diabetes Mellitus & 0.848 \\
\hline & Hyperlipidemia & 0.892 \\
\hline & Chronic & \\
\hline & Failure & 0.405 \\
\hline & Smoking & 0.03 \\
\hline & Treatment Use Prior & \\
\hline & to Stroke & 0.166 \\
\hline
\end{tabular}

LVWMA: Left Ventricle Wall Motion Abnormality 


\section{DISCUSSION}

Stroke is a common pathology worldwide, and it is one of the leading neurological emergencies. The prevalence varies among countries. The estimated rate of ischemic stroke is $87 \%$, intracerebral hemorrhage is $13 \%$, and subarachnoid hemorrhage is $3 \%$ in the United States of America ${ }^{13}$. When less-developed countries are involved, the rate of ischemic stroke decreases to 68\%; however, the intracerebral hemorrhage rate increases to $32 \%{ }^{14}$.

The main underlying pathology of ischemic stroke is atherosclerosis, and the prevalence of ischemic stroke is increasing in patients with older age. For instance, atherosclerosis is observed in $43 \%$ of the patients between 60 to 69 years old, $65 \%$ of the patients between 70 to 79 years old, and over $80 \%$ in patients over 80 years old ${ }^{15}$. A computerized tomography study from Holland showed that atherosclerosis in the internal carotid artery was found in $82 \%$ of individuals over the age of 5516. Likewise, we observed that the rate of atherosclerotic stroke was higher in patients with older age and less of them have cardioembolic stroke in our study. The prevalence of cardioembolic stroke is increasing in developed countries due to the effective prevention of HT and HPL, which are more prominent risk factors for atherosclerotic stroke. Even the incidence of stroke is decreasing, the presence of cardioembolic stroke has increased 3 times higher in the past decades $^{17}$. Consistent with literature, the present study showed that cardioembolic stroke is less than atherosclerotic stroke. The main underlying reason is the increased rates of well-known risk factors for atherosclerotic strokes such as HT, smoking, HPL, and DM and they are not treated well. In addition, risk factors such as HPL, HT, smoking, and DM accompany ischemic stroke in our study.

According to USA data, there are 795000 ischemic stroke patients annually, and 185000
(23.2\%) of these patients have recurrent strokes ${ }^{13}$. In our data, we observed that $23.5 \%$ of our patients had $\geq 2$ recurrences, and it is compatible with other studies. Even our patients have many risk factors for ischemic stroke; we observed that $49 \%$ of them did not use any antiaggregant or anticoagulant therapy and 39\% of them were receiving ASA prior to stroke. Despite having multiple risk factors, patients not receiving appropriate and sufficient treatments for primary and secondary stroke prophylaxis is one of the leading reasons for both first stroke and recurrent cases. Many studies have shown that regular use of antihypertensives, appropriate HPL treatment, and decreasing blood glucose reduce the frequency of recurrent stroke ${ }^{18}$.

In addition, it was observed that atherosclerotic strokes were more common in smokers in our study. Smoking is one of the most common risk factors for vascular pathologies such as ischemic stroke and myocardial infarction (MI). In a study investigating the effects of smoking on stroke, MI, and death, it was observed that the 5-year risk of stroke-MI-death was $22.6 \%$ in the smoking group, while this rate was $15.7 \%$ in the non-smoking group, and a statistically significant difference was found between these two groups ${ }^{19}$. For this reason, it is important that clinicians should evaluate risk factors while assessing patients, recommend lifestyle changes, and apply appropriate treatments as soon as possible.

The evaluation of ECHO findings showed that $10 \%$ of the patients had heart failure, approximately one-third of the patients had increased left atrial width, and accompany left ventricular segmental motion defect. Akinetichypokinetic segments developing under these pathologies lead to cardiac thrombus, especially in the presence of $\mathrm{AF}^{20}$. The thrombus causes cardioembolic stroke, and these patients have a 3 -fold higher risk of stroke ${ }^{21}$. It is obvious that 
patients with AF have more cardioembolic stroke than atherosclerotic etiology.

There is still no consensus on which method should be investigated for detecting AF. In a multi-center study, ECG, H-ECG, and mobile cardiac telemetry data of the patients were examined during the emergency service and hospital admissions. The rates of AF detection were $7.7 \%, 5.1 \%, 10.7 \%$, and $16.7 \%$, respectively. The analysis of all data showed that the rate of AF detection after stroke was $23.7 \%^{22}$.

Considering that the rates of $\mathrm{AF}$ and PAF were $21.1 \%$ in our study, the present finding is compatible with the literature. The effective treatment of $\mathrm{AF}$ in patients with ischemic stroke significantly reduces the risk of recurrence; therefore, the presence of AF should be investigated insistently in patients with increased left atrial width and patients with anterior-posterior circulation infarction simultaneously ${ }^{23}$.

\section{CONCLUSION}

Atherosclerosis is more common in patients with ischemic stroke, and there are many risk factors such as smoking, HPL, and HT. Considering the presence of recurrent strokes in our patients, appropriate prevention should be applied to prevent recurrent strokes. The presence of AF should be investigated in all patients, especially those with left atrium enlargement on ECHO.

Ethics Committe Approval: This study was approved by the İzmir Katip Çelebi University Faculty of Medicine Ethics Committee (Decision Date: 22.10.2020, 1005 Approval Number). It was conducted in accordance with the Helsinki Declaration, and informed consent was provided by all the participants.

Decleration of Conflicting Interest: The authors declare no conflict of interest.
Financial Disclosure: The authors declare no financial support fort his study.

\section{REFERENCES}

1. Guzik A, Bushnell C. Stroke Epidemiology and Risk Factor Management. Continuum (Minneap Minn) 2017; 23: 15-39. https://doi.org/10.1212/CON.0000000000000416

2. Sacco RL, Kasner SE, Broderick JP, et al. American Heart Association Stroke Council, Council on Cardiovascular Surgery and Anesthesia; Council on Cardiovascular Radiology and Intervention; Council on Cardiovascular and Stroke Nursing; Council on Epidemiology and Prevention; Council on Peripheral Vascular Disease; Council on Nutrition, Physical Activity and Metabolism. An updated definition of stroke for the 21st century: a statement for healthcare professionals from the American Heart Association/American Stroke Association. Stroke 2013; 44: 2064-89. https://doi.org/10.1161/STR.0b013e318296aeca.

3. Hankey GJ. Stroke. Lancet 2017; 11: 641-54. https://doi.org/10.106/S0140-6736(16)30962-X.

4. Vangen-Lønne AM, Wilsgaard T, Johnsen SH et al. Declining Incidence of Ischemic Stroke: What Is the Impact of Changing Risk Factors? The Tromso Study 1995 to 2012. Stroke 2017; 48: 544-50. https://doi.org/10.1161/STROKEAHA.116.014377.

5. Madsen TE, Khoury JC, Leppert M et al. Temporal Trends in Stroke Incidence Over Time by Sex and Age in the GCNKSS. Stroke 2020; 52: 1070-76. https://doi.org/10.1161/STROKEAHA.120.028910.

6. Öztürk Ü, Öztürk Ö, Nergiz Ş et al. Relationship Between Paraoxonase-1 Activity and Pulse Pressure Index in Patients with a Acute Ischemic Stroke. Dicle Med J 2020; 47: 820-27. https://doi.org/10.5798/dicletip.850304.

7. van Alebeek ME, Arntz RM, Ekker MS et al. Risk Factors and Mechanisms of Stroke In Young Adults: The FUTURE Study. J Cereb Blood Flow Metab 2018; 38:

1631-41. https://doi.org/10.1177/0271678X17707138.

8. The Leading Cause of Mortality in Turkey, 2018. http://www.tuik.gov.tr/PreHaberBultenleri.do?id= 30626. 
9. Deaths and Mortality, Data are For The U.S. https://www.cdc.gov/nchs/fastats/deaths.htm.

10. Zhang L, Li X, Wang D et al. Risk Factors of Recurrent Ischemic Events after Acute Noncardiogenic Ischemic Stroke. Curr Pharm Des 2019; 25: 4827-34. https://doi.org/10.2174/13816128256661910291 03756.

11. O'Donnell MJ, Xavier D, Liu $L$ et al. and INTERSTROKE investigators. Risk Factors for Ischaemic and Intracerebral Haemorrhagic Stroke in 22 Countries (the INTERSTROKE study): A CaseControl Study. Lancet 2010; 376: 112-23. https://doi.org/10.1016/S0140-6736(10)60834-3.

12. Wachter R, Gröschel K, Gelbrich Get al; Find-AF (randomised) Investigators and Coordinators. Holter-electrocardiogram-monitoring in Patients with Acute Ischaemic Stroke (Find-AF RANDOMISED): An Open-label Randomised Controlled Trial. Lancet Neurol 2017; 16: 282-90. https://doi.org/10.1016/S1474-4422(17)30002-9.

13. Virani SS, Alonso A, Benjamin EJ et al.; American Heart Association Council on Epidemiology and Prevention Statistics Committee and Stroke Statistics Subcommittee. American Heart Association Council on Epidemiology and Prevention Statistics Committee and Stroke Statistics Subcommittee. Heart Disease and Stroke Statistics-2020 Update: A Report From the American Heart Association. Circulation 2020; 141: e139e596.

https://doi.org/10.1161/CIR.0000000000000757.

14. Krishnamurthi RV, Feigin VL, Forouzanfar MH et al.; Global Burden of Diseases, Injuries, Risk Factors Study 2010 (GBD 2010); GBD Stroke Experts Group. Global and regional burden of first-ever ischaemic and haemorrhagic stroke during 1990-2010: findings from the Global Burden of Disease Study 2010. Lancet Glob Health 2013; 1: e259-81. https://doi.org/10.1016/S2214-109X(13)70089-5.

15. Banerjee C, Chimowitz MI. Stroke Caused by Atherosclerosis of the Major Intracranial Arteries. Circ Res 2017; 120: 502-13.
https://doi.org/10.1161/CIRCRESAHA.116.308441

16. Bos D, van der Rijk MJ, Geeraedts TE et al. Intracranial Carotid Artery Atherosclerosis: Prevalence and Risk Factors in the General Population. Stroke 2012; 43:1878-84. https://doi.org/10.1161/STROKEAHA.111.648667.

17. Yiin GS, Howard DP, Paul NL et al.; Oxford Vascular Study. Age-specific incidence, outcome, cost, and projected future burden of atrial fibrillation-related embolic vascular events: a population-based study. Circulation 2014; 130:1236-44.

https://doi.org/10.1161/CIRCULATIONAHA.114.0 10942.

18. Oza R, Rundell K, Garcellano M. Recurrent Ischemic Stroke: Strategies for Preventation. Am Fam Physician 2017; 96: 436-40.

19. Epstein KA, Viscoli CM, Spence JD et al.; IRIS Trial Investigators. Smoking cessation and outcome after ischemic stroke or TIA. Neurology 2017; 89: 172329.

https://doi.org/10.1212/WNL.000000000000452 4.

20. Lip GY, Gibbs CR. Does heart failure confer a hypercoagulable state? Virchow's triad revisited. J Am Coll Cardiol 1999; 33:1424-26. https://doi.org/10.1016/s0735-1097(99)00033-9

21. Witt BJ, Brown RD Jr, Jacobsen SJ et al. Ischemic stroke after heart failure: a community-based study. Am Heart J 2006; 152:102-9. https://doi.org/10.1016/j.ahj.2005.10.018.

22. Sposato LA, Cipriano LE, Saposnik G, et al. Diagnosis of atrial fibrillation after stroke and transient ischaemic attack: a systematic review and meta-analysis. Lancet Neurol 2015; 14: 377-87. https://doi.org/10.1016/S1474-4422(15)70027-X.

23. Sposato LA, Cerasuolo JO, Cipriano LE et al.; PARADISE Study Group. Atrial fibrillation detected after stroke is related to a low risk of ischemic stroke recurrence. Neurology 2018; 90: 924-31. https://doi.org/10.1212/WNL.000000000000516. 